\title{
Interdecadal variability in predator-prey interactions of juvenile North Pacific albacore in the California Current System
}

\author{
Sarah M. Glaser \\ Integrative Oceanography Division, Scripps Institution of Oceanography, University of California, San Diego, La Jolla, \\ California 92093-0218, USA \\ Present address: Department of Ecology and Evolutionary Biology, University of Kansas, Lawrence, Kansas 66047, USA
}

\begin{abstract}
Predator-prey interactions are critical components of multispecies models, and most attempts to quantify these interactions in pelagic marine environments rely on observational diet studies. In conjunction with 3 historical studies, a new diet study quantifies decadal patterns of predator-prey interactions for juvenile North Pacific albacore Thunnus alalunga in the California Current System (CCS). Juvenile albacore in the CCS eat young-of-year prey and derive 68 to $89 \%$ of nutrition from fishes, 9 to $30 \%$ from cephalopods, and the remainder from crustaceans. Despite resurgence in abundance of Pacific sardine Sardinops sagax in the CCS, only Northern anchovy Engraulis mordax, Pacific saury Cololabis saira, and cephalopods have consistently been important to albacore diet. These results support theoretical predictions of optimal foraging models that albacore will prefer hunting in cold, near-shore waters containing anchovy and saury while minimizing foraging in warmer, offshore waters of sardine habitat. A bioenergetics model is used to calculate daily and annual consumption rates. The importance of calculating an ensemble prey energy density $\left(E D_{n}\right)$ value for steady-state consumption models is demonstrated, and the relationship between $E D_{n}$ and consumption rates is generalized to other marine predators. Low variability in $E D_{n}$ consumed by juvenile albacore translates into equally stable consumption to biomass $(Q: B)$ ratios over decades.
\end{abstract}

KEY WORDS: Thunnus alalunga · Predator-prey interaction · Bioenergetics · Ensemble energy density · Diet · Trophic ecology $\cdot$ Pelagic food web · California Current

\section{INTRODUCTION}

The aims of this study were to identify critical relationships between juvenile North Pacific albacore and their prey in the California Current System (CCS), and to quantify decadal variability in diet and consumption rates. Diet studies are a snapshot of the habits of marine predators. In light of significant ecological changes in the CCS over the past half-century (e.g. Hare \& Mantua 2000, McGowan et al. 2003, Brodeur et al. 2005, Lavaniegos \& Ohman 2007), and given functional redundancy in marine food webs (Link 2007) and the commonality of generalist foraging strategies (Roughgarden 1974), variability in diet is expected.
North Pacific albacore Thunnus alalunga are highly migratory predators that produce 60000 to $100000 \mathrm{t}$ of commercial landings annually (ISC 2006). Adults spawn in the western-central North Pacific and juveniles (ages 0 to 4 ) occupy the productive California and Kuroshio Current regions (Laurs \& Lynn 1977). Juvenile albacore migrate into CCS waters in the late spring and reside there until late fall. Some juveniles over-winter at the southern end of the CCS along the Baja continental shelf, while some migrate across the North Pacific to the Kuroshio system (Kimura et al. 1997). Albacore complete $90 \%$ of growth before reproductive maturity (de Zarate \& Restrepo 2001); given 
the residence time of juveniles in the CCS, their diet in this region is important to the production of the population.

Diet habits of juvenile albacore in the CCS have been described in a host of studies (Hart et al. 1948, Pearcy 1973, Bernard et al. 1985). Three notable studies (McHugh 1952, Iversen 1962 [in conjunction with Graham 1959], Pinkas et al. 1971) are sufficient in scope for interdecadal comparisons. Data collected by Pinkas et al. (1971), in particular, are widely used to parameterize ecosystem models (Kitchell et al. 1999, Olson \& Watters 2003, Field et al. 2006). These 3 historical diet studies have never been analyzed in concert. Given the widespread presumption that albacore are opportunistic predators (Pinkas et al. 1971, Watanabe et al. 2004, Consoli et al. 2008), an updated diet study is warranted.

Significant fluctuations in population sizes of 2 forage fishes, Sardinops sagax (Pacific sardine) and Engraulis mordax (Northern anchovy), have occurred asynchronously over the past century (Soutar \& Isaacs 1974, Schwartzlose et al. 1999, Baumgartner et al. 1992, Chavez et al. 2003). Past studies (McHugh 1952, Iversen 1962, Pinkas et al. 1971, Bernard et al. 1985) have identified anchovy, but not sardine, in significant quantities in juvenile albacore diet. However, those studies were conducted during periods of high anchovy and low sardine abundance (Jacobson et al. 1995, Hill et al. 2007). Recently, the relative abundance of these small pelagic fishes has reversed (Hill et al. 2007). Given the biological similarities between these forage species, it is reasonable to hypothesize that juvenile albacore have increased predation on sardine and decreased predation on anchovy.

Predator-prey interactions are critical components of multispecies models, and empirical attempts to quantify interaction strengths rely upon diet studies or field observations of predation. Diet studies are especially useful in poorly observed systems, such as the pelagic environment, where interaction strengths are difficult to quantify (Wootton 1997). For pelagic predators, gut content studies remain the primary method for measuring food web linkages. Estimating variability in diet-derived parameters is a critical step in improving multispecies and ecosystem-based models (Christensen \& Walters 2004).

Multispecies models have shown great promise for estimating recruitment and natural mortality, quantifying fishing impact on community structure, and describing climate effects on food webs (e.g. Cox et al. 2002, Watters et al. 2003, Christensen \& Walters 2004, Field et al. 2006). However, the complexity inherent in these models obscures more finely resolved components, such as species-level dynamics (Hollowed et al. 2000). Species-specific parameters in ecosystem-scale models, such as the consumption to biomass ratio $(Q: B)$, can be calculated within the models themselves, but it is important also to validate estimates empirically.

$Q: B$ quantifies prey biomass consumed per unit biomass of a predator population on an annual basis (Pauly 1989). This parameter can be used, among other things, to estimate the predation pressure exerted on prey populations and to predict how a predator population may be affected by changes in prey abundance. The potential for sudden and unexpected fluctuations in marine populations, especially fisheries, underscores the importance of predicting community responses to changing climate and fishing pressure (Hare \& Mantua 2000, Pauly et al. 2002, Hsieh et al. 2005). Thus, estimates of $Q: B$ that are empirically derived for a given species are important for informing adaptive ecosystem-based management.

This study presents new data quantifying diet habits of juvenile albacore in the CCS, and, in the context of 3 prior studies, investigates changes over time. Historical studies are re-analyzed using a contemporary bioenergetics approach, and estimates of energetic demand are used to calculate $Q: B$ for juvenile albacore. This is the first study to quantify empirically, for albacore, the suite of prey energy density $(E D)$ values consumed and the impacts of variable prey on consumption rates. Results demonstrate that juvenile albacore rely on few species of prey to meet energetic requirements in the CCS.

\section{MATERIALS AND METHODS}

Data collection (present study). Stomachs from 371 juvenile North Pacific albacore were collected during June to September 2005 and 2006 (Fig. 1). Stomachs were collected by the author on recreational boats $(\mathrm{n}=$ 188) and by captains and crew on 2 commercial boats $(n=183)$. All boats used troll gear, poles, or hand lines. In all cases, date and location were recorded. Time of day and albacore length were recorded on recreational vessels. Stomachs were removed on deck from fish minutes after death and frozen with dry ice or in a blast freezer; a small percentage $(\sim 10 \%)$ were collected at docks from vessels returning from day trips.

Contents were identified visually by the author exclusively, primarily utilizing fish vertebrae (Clothier 1952), fish otoliths (Harvey et al. 2000), cephalopod beaks (Pinkas et al. 1971, Clarke 1986), and crustacean body and eyeball morphology to identify species to the lowest taxonomic level possible. Unidentifiable remains, tissue from Sebastes spp. (rockfishes), and voucher specimens of juvenile cephalopods were sequenced for genetic identification. Lengths of individual prey items 


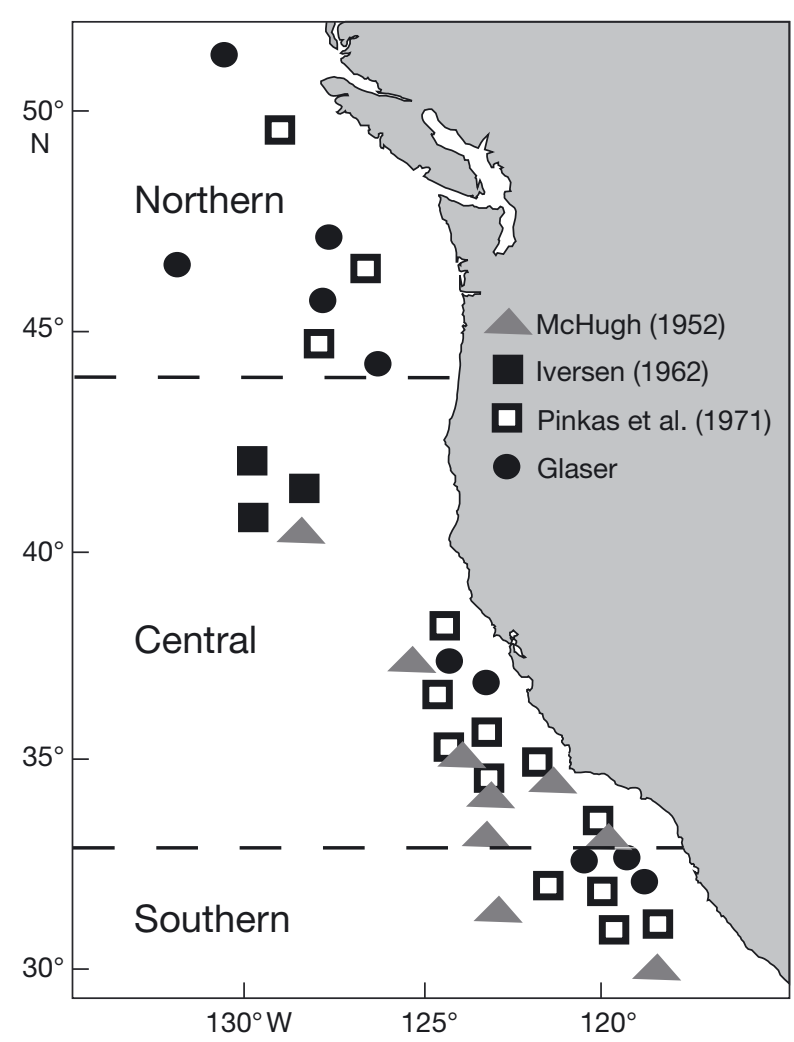

Fig. 1. Distribution of sampling effort for 4 studies of juvenile albacore diet in the California Current System

were measured to reconstruct original (pre-digestion) weights. If a stomach contained a large number of one species, 5 randomly chosen representatives per stomach were measured.

Data collection (historical studies). McHugh (1952) collected 321 stomachs during the summers of 1949 and 1950 using unbaited poles (Fig. 1, based on McHugh Fig. 1). Albacore lengths were not provided. McHugh reported mean volumes of individual prey, total volume of species consumed, and frequency of occurrence, but not numbers consumed.

Graham (1959) and Iversen (1962) reported independent results from one study and data are combined here (hereafter, jointly referred to as Iversen 1962). Investigators collected stomachs between 1950 and 1957 using longline, gill net, and troll gear. Only those collected by troll gear ( $\mathrm{n}=155$ and starting in 1954) are analyzed here. Other sampling methods are not comparable due to location or gear bias. Trolling occurred primarily in the CCS, but some $(n=38)$ were collected further west (Fig. 1, based on Iversen Table 1) and could not be excluded from the gear-aggregated results. Sampling occurred during fall and winter 1954, 1955, and 1956 and summer 1955, 1956, and 1957. Iversen reported frequency of occurrence, number, and volume of prey items while Graham reported numeric data only.
Pinkas et al. (1971) collected 905 albacore from commercial vessels using troll gear. Sampling took place during July to November 1968 and July to September 1969 (Fig. 1, based on their Fig. 4). They reported frequency of occurrence, number, and volume of prey for each of 3 regions (southern, central, and northern CCS).

Data analysis. Stomachs were assigned to one of 3 regions in the California Current based on the regional divisions established by Pinkas et al. (1971). Regions were designated northern (north of $44^{\circ} \mathrm{N}$ latitude, inclusive), central (between $33^{\circ}$ and $44^{\circ} \mathrm{N}$ latitude) and southern (south of $33^{\circ} \mathrm{N}$ latitude, exclusive). The northern region lacks data from McHugh (1952) and Iversen (1962) and the southern region lacks data from Iversen (1962).

The energetic contribution $(E)$ of prey to the diet of juvenile albacore is $E_{i}=W_{i} \times E D_{i}$ where $W_{i}$ is wet weight $(\mathrm{g})$ and $E D_{i}$ is energy density $\left(\mathrm{kJ} \mathrm{g}^{-1}\right)$ of species i. Published values of prey ED and proximate composition were collected. Only 'whole body' values reported as wet weight were used. If $E D$ for a species was unavailable, the next highest taxonomic level was used (see supplement at www.int-res.com/articles/ suppl/m414p209_supp.pdf for details).

The taxonomic resolution of prey and diet metrics in the 4 studies varied. Any prey category that occurred in at least 10 stomachs in any of the 4 studies was analyzed. The degree of digestion was not reported in the historical studies, complicating comparisons of mass data. Therefore, numbers of prey were converted to pre-digested weight using published allometric length-weight relationships. The mean length of prey from 2005-2006 was applied to historical studies. This was justified by the similarity in prey sizes described (see Discussion). For McHugh (1952), percent volume was used directly because numeric data were not reported.

Pre-digested weight was reconstituted as follows. Allometric length-weight relationships were used for all species of fish (Harvey et al. 2000, Froese \& Pauly 2008). For crustaceans, measurements of carapace length and wet weight were used (Isaacs et al. 1969). For cephalopods, measurements of beak lower rostral length (LRL) were used to calculate wet weight. The LRL of cephalopod beaks in this study ranged from 0.2 to $2.0 \mathrm{~mm}$. LRL-weight relationships for this range of beak sizes exist for Loligo opalescens, Gonatus sp., Onychoteuthis borealijaponica, and Abraliopsis sp. (Wolff 1984, Clarke 1986). Body masses were calculated for these 4 species, and the overall mean was applied to remaining cephalopod species.

A bioenergetics model of albacore (Essington 2003) was used to calculate daily consumption rates. Daily consumption $(C)$ is $C=A L+S M R+A M R+R E P+G$, 
where $A L$ is loss from assimilation, $S M R$ is standard metabolic rate, $A M R$ is active metabolic rate, $R E P$ is reproduction, and $G$ is somatic growth. Here, $A L$ describes the loss of energy due to feces (10\%), excretion (10\%), and specific dynamic action (15\%) (Olson \& Boggs 1986). All components have units of $\mathrm{J} \mathrm{kg}^{-1} \mathrm{~d}^{-1}$. The model is size- and age-explicit, and includes swimming speed, lift, sex ratio (1:1), and age of reproductive maturity. To quantify the steady-state biomass $\left(\mathrm{g} \mathrm{kg}^{-1} \mathrm{~d}^{-1}\right.$ ) of prey consumed $\left(C_{\mathrm{B}}\right), C$ was multiplied by prey $E D^{-1}$. Finally, to calculate annual $Q: B, C_{\mathrm{B}}$ was multiplied over the year.

Parameter uncertainty was quantified by running 10000 Monte Carlo simulations of the model. Essington (2003) found $Q: B$ sensitive to $10 \%$ perturbations of $A L$, swimming speed $\left(x_{\text {swim }}\right)$, the slope of the line relating $A M R$ to swimming speed $\left(x_{A M R}\right)$, and $E D$. In the simulation, $A L, x_{\text {swim }}$ and $x_{A M R}$ varied by $10 \%$ and $E D$ varied according to the distributions in the literature.

The bioenergetics model was given a temporal component by varying diet according to the historical studies and by sampling from the age distribution of albacore in the CCS. The energy consumed is a weighted combination of the ED of prey and the proportion that prey comprises of total intake. Using the percentage weight a taxon contributed to albacore diet, an ensemble energy density value $\left(E D_{n}\right)$ was calculated for each study (simply, a weighted mean). To calculate $E D_{n}$ for any non-study year $x$, a weighting function accounted for the distance of year $x$ from the 2 studies flanking $x$ in time $(i$ and $i+1)$, such that

$E D_{n x}=\left[1-\left(\frac{t_{x}-t_{i}}{t_{i+1}-t_{i}}\right)\right] \times E D_{n i}+\left[1-\left(\frac{t_{i+1}-t_{x}}{t_{i+1}-t_{i}}\right)\right] \times E D_{n i+1}$

where $t$ is the year of study $i$ or the non-study year $x$. $C$ and $C_{B}$ are functions of albacore age, therefore the age-distribution of juvenile North Pacific albacore landed by the North American commercial troll fishery from 1966 to 2005 was used to create a distribution from which the simulation sampled. This fishery operates primarily in the CCS and targets juveniles (ISC 2006). To extrapolate for the time period 1949 to 1965 , overall age distribution was used. In each iteration, the following variables were randomly sampled from their distributions: $A L, x_{A M R}, x_{\text {Swim, }} E D$, and albacore size/age. $E D_{n}, C_{\mathrm{B}}$ and $Q: B$ were calculated along with estimates of uncertainty.

\section{RESULTS}

The 4 studies describe diet habits of 1672 juvenile albacore in the CCS at various points during a period spanning 55 yr. Albacore were between 52 and $105 \mathrm{~cm}$ in fork length (Table 1), corresponding to age groups of
2 to 3 yr old (Suda 1966). Albacore of this size allocate approximately $10 \%$ of energetic intake to growth, 20 to $25 \%$ to active metabolism (swimming), $40 \%$ to standard metabolism, and the balance is lost (Essington 2003 and values calculated here).

In the CCS, juvenile albacore consumed young-ofyear (YOY) fishes, juvenile cephalopods, and adult zooplankton (Table 2). Juvenile albacore were capable of consuming adult-sized small pelagic fishes, evidenced by the size of bait in stomachs (Table 2). However, excluding bait and saury Cololabis saira, their mean prey was recently spawned fishes 15 to $65 \mathrm{~mm}$ in length and cephalopods weighing $4 \mathrm{~g}$. The Pacific saury was notable because it was relatively larger than other prey $(119.1 \pm 68.3 \mathrm{~mm}, 13.0 \pm 20 \mathrm{~g}$, mean $\pm \mathrm{SD})$ and the large SD indicated both juvenile and adult saury were eaten. In comparison, anchovy Engraulis mordax were consistently of juvenile sizes $(34.7 \pm 10.0 \mathrm{~mm}, 1.1 \pm 1.3 \mathrm{~g})$. The remainder of fishes were also juveniles except myctophids, which, while small $(50.1 \pm 15.8 \mathrm{~mm})$, were adults. Juvenile rockfish Sebastes spp. (14.5 $\pm 4.5 \mathrm{~mm})$ were a common prey item and were the smallest fish regularly consumed by albacore. Cephalopods were juvenile sizes, and crustaceans (amphipods, decapods, and euphausiids) were adult sizes. While bait boats harvested anchovy and sardine Sardinops sagax 15 to $20 \mathrm{~cm}$ in length for fishing vessels, the natural prey of albacore were considerably smaller.

Table 3 summarizes preyED values synthesized from the literature and used in the bioenergetics model. Crustaceans and cephalopods were significantly lower in energy content than fishes, although some species of squid were more comparable to fishes. Of the species consumed by albacore, crustaceans ranged from 2.5 to $3.2 \mathrm{~kJ} \mathrm{~g}^{-1}$, cephalopods from 3.0 to $6.7 \mathrm{~kJ} \mathrm{~g}^{-1}$, and fishes from 3.5 to $7.9 \mathrm{~kJ} \mathrm{~g}^{-1}$ (see supplement for detailed values).

Depending on the $E D_{n}$ of the albacore prey, daily consumption rates could range from 0.02 to $0.12 \mathrm{~g} \mathrm{~g}^{-1}$ $\mathrm{d}^{-1}$ for an age-3 albacore (mean length $65 \mathrm{~cm}$ ) (Fig. 2). The relationship between biomass consumed and $E D_{n}$

Table 1. Thunnus alalunga. Collection years, and fork lengths of juvenile albacore (parentheses: SD) examined in 4 diet studies and from commercial catch (ISC 2006)

\begin{tabular}{|lccc|}
\hline $\begin{array}{l}\text { Collection } \\
\text { years }\end{array}$ & $\begin{array}{c}\text { Mean length } \\
(\mathrm{cm})\end{array}$ & $\begin{array}{c}\text { Range } \\
(\mathrm{cm})\end{array}$ & Source \\
\hline $1949-1950$ & $\mathrm{n} / \mathrm{a}$ & $\mathrm{n} / \mathrm{a}$ & McHugh (1952) \\
$1954-1958$ & $\sim 67$ & $53-85$ & Iversen (1962) \\
$1968-1969$ & $\mathrm{n} / \mathrm{a}$ & $52-93$ & Pinkas et al. (1971) \\
$2005-2006$ & $75.6(8.9)$ & $54-99$ & Glaser (this study) \\
$1966-2005$ & $68.4(6.5)$ & $37-105$ & ISC (2006) \\
\hline
\end{tabular}


Table 2. Thunnus alalunga. Measured lengths and calculated weights of prey categories common to 4 studies of juvenile albacore diet, mean (SD). Measurements were made from stomach contents collected in 2005-2006 (this study). Mass values from length-weight relationships were applied to numeric data from historical studies to reconstruct the pre-digestion wet weights of prey. $\mathrm{n}$ is the number of specimens measured

\begin{tabular}{|c|c|c|c|c|}
\hline Prey category & $\mathrm{n}$ & Length (mm) & $\mathrm{n}$ & Weight $^{\mathrm{a}}(\mathrm{g})$ \\
\hline \multicolumn{5}{|l|}{ Crustaceans } \\
\hline Amphipods & 47 & $11.7^{\mathrm{b}}(6.5)$ & 8 & $0.04(0)$ \\
\hline Pleuroncodes planipes & 2 & $33.8^{\mathrm{b}}(2.5)$ & 1 & 2.0 \\
\hline Euphausiids & 30 & $23.0^{\mathrm{b}}(4.8)$ & 8 & 0.1 \\
\hline Malacostracans & 24 & $26.3^{\mathrm{b}}(8.4)$ & 1 & 0.1 \\
\hline Cephalopods & 181 & $0.8^{\mathrm{c}, \mathrm{f}}(0.2)$ & 181 & $3.8^{\mathrm{f}}(4.0)$ \\
\hline \multicolumn{5}{|l|}{ Fishes } \\
\hline Cololabis saira & 87 & $119.1^{\mathrm{d}}(68.3)$ & 87 & $13.0(20.0)$ \\
\hline Engraulis mordax & 421 & $34.7^{\mathrm{d}}(10.0)$ & 421 & $1.1(1.3)$ \\
\hline Sardinops sagax & 128 & $49.2^{\mathrm{d}}(16.9)$ & 128 & $1.8(3.6)$ \\
\hline Sebastes spp. & 29 & $14.5^{\mathrm{d}}(4.5)$ & 29 & $0.1(1.0)$ \\
\hline Merluccius productus & 232 & $60.9^{\mathrm{e}}(15.3)$ & 232 & $2.1(2.0)$ \\
\hline Trachurus symmetricus & 7 & $64.7^{\mathrm{e}}(39.3)$ & 7 & $12.5(17.6)$ \\
\hline Myctophidae & 16 & $50.1^{\mathrm{e}}(15.8)$ & 16 & $1.9(1.4)$ \\
\hline Fishes (other) & 942 & $49.7^{\mathrm{f}, \mathrm{g}}(34.9)$ & 942 & $2.5^{\mathrm{f}, \mathrm{g}}(7.3)$ \\
\hline Enqraulis mordax bait & 29 & $100.0^{\mathrm{d}}(22.8)$ & 29 & $13.6(7.0)$ \\
\hline Sardinops sagax bait & 39 & $145.5^{\mathrm{d}}(16.2)$ & 39 & $33.0(12.9)$ \\
\hline Scomber japonicus bait & 8 & $227.7^{\mathrm{e}}(36.1)$ & 8 & $60.9(21.5)$ \\
\hline
\end{tabular}

saury, and cephalopods, based on percent energetic contribution $(E)$. Table 4 describes the spatial and temporal patterns evident in juvenile albacore diet, to the extent that data were available.

In the northern region, anchovy were the largest single-species component of diet; however, anchovy were far more predominant (68\% versus $30 \%$ ) in 1968-1969 than in 20052006. In the late 1960s, cephalopods were the second most important prey group (14\%). All other taxa each comprised less than $10 \%$ of the diet, with saury (8\%), myctophids (5\%), and crustaceans $(4 \%)$ being notable. In 2005-2006, the sum of all crustaceans comprised the largest component of the diet $(31.5 \%)$; the group Crustaceans was primarily undifferentiated decapods or euphausiids. Juvenile hake appeared in albacore diet for the first time on record in 2005-2006 and were the second most important (21\%) single-species prey group in the northern region, followed by cephalopods $(5 \%)$ and juvenile sardine $(4 \%)$.

The central region contained data from all 4 diet studies and showed, overall, a predominance of saury and cephalopods in the diet, with important exceptions. Anchovy were the most important (38\%) prey in 1949-1950, while hake were the most important (38\%) during 2005-2006. In these 2 studies, saury and cephalopods were, respectively, the second and third most important prey groups, whereas they were the first and second most important groups during the intervening studies (1954-1957 and 1968-1969). Cephalopods dominated diet in the central region in 1968-1969 (63\%), the highest contribution of cephalopods in any interval. Crustaceans were a less important component of diet here, comprising only 1 to $10 \%$ of $E$.

Diet in the southern region, generally speaking, was dominated by the same prey: saury was the most important group in 1949-1950 (61\%) and 1968-1969 $(59 \%)$, while cephalopods were either the second or third most important group in all 3 studies available. In the earliest study, crustaceans comprised the second most important group (11\%). Anchovy were important in 1968-1969 (17\%) and 2005-2006 (67\%) but were not significant in 1949-1950. Notably, sardine was the second most important component of diet (15\%) in this region during the 2005-2006 study, and hake were not present. varies geometrically: $C_{\mathrm{B}}=C \times E D^{-1}$. Thus, the sensitivity of the model depends on the magnitude of $E D_{n}$. Due to the high proportion of fish in albacore diet, the 4 studies cluster along the flat portion of the curve relating consumption rates to prey ED (Fig. 2).

In general, over a period of $55 \mathrm{yr}$ and 3 regions of the CCS, albacore primarily consumed anchovy, 


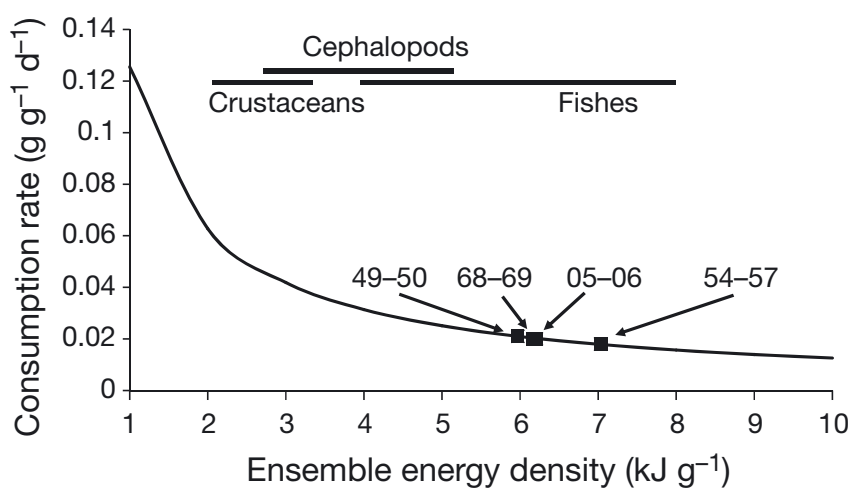

Fig. 2. Thunnus alalunga. Influence of prey energy density $(E D)$ on steady-state daily consumption rates of juvenile albacore. Rates were calculated according to Essington (2003) for age-3 albacore (mean weight $5.9 \mathrm{~kg}$ ). The ensemble energy density (a weighted mean, $E D_{n}$ ) calculated for the 4 diet studies is marked. The range of $E D$ values for prey species is shown for reference

$E D_{n}$ estimated for the 4 studies was comparable, ranging from 6.0 to $7.0 \mathrm{~kJ} \mathrm{~g}^{-1}$ with low variability (Table 5). A juvenile albacore feeding in the CCS consumed between 18.0 to $21.0 \mathrm{~g}$ of prey per $\mathrm{kg}$ of body mass per day $\left(C_{\mathrm{B}}\right)$. Using an age-3 albacore $(5.9 \mathrm{~kg}$, $65 \mathrm{~cm}$ ) as an example, this estimate of $C_{\mathrm{B}}$ translates into a steady-state energetic intake of between 106.2 and $123.9 \mathrm{~g}$ per albacore per day.

The mean annual $Q: B$ was consistent between studies and ranged from 6.7 to $8.0 \mathrm{yr}^{-1}$ (Fig. 3). The greatest variability occurred early in the time series when 3 diet studies were close in time. The studies in the late 1960s and 2005-2006 had similar $E D_{n}$ values and the $Q: B$ line is relatively flat through this period. Given the wide temporal spacing between these studies, it is impossible to know whether changes in diet (and hence changes in $Q: B$ ) were gradual or sudden; the weighting function used here assumed the former.

\section{DISCUSSION}

\section{Spatial and temporal patterns}

This study presents observational evidence that only 2 or 3 species of fish were important prey items for juvenile albacore in the CCS. Based on 4 diet studies, juvenile albacore obtain greater than $60 \%$ of their total energetic intake from 2 species of coastal pelagic fish: Northern anchovy Engraulis mordax and Pacific saury Cololabis saira. These results have been consistent over $50 \mathrm{yr}$ and are corroborated by other studies of juvenile albacore (not analyzed here due to scope) which found saury and anchovy were dominant prey off Vancouver Island during 1941-1947 (Hart et al.
Table 4. Thunnus alalunga. Energetic contribution $(E, \%)$ of prey to diet of juvenile albacore in the California Current. Studies are: McHugh (1952), Iversen (1962), Pinkas et al. (1971), and Glaser (this study). Columns are years data were collected. Prey categories represent taxa in common to the 4 studies, in general distinguishing any species category accounting for $\geq 1 \%$ of $E$

\begin{tabular}{|c|c|c|c|c|}
\hline Prey category & $\begin{array}{c}1949- \\
1950\end{array}$ & $\begin{array}{c}1954- \\
1957\end{array}$ & $\begin{array}{c}1968- \\
1969\end{array}$ & $\begin{array}{c}2005- \\
2006\end{array}$ \\
\hline \multicolumn{5}{|l|}{ Northern } \\
\hline Amphipods & - & - & 0.0 & 0.7 \\
\hline Pleuroncodes planipes & - & - & 0.0 & 0.0 \\
\hline Euphausiids & - & - & 0.0 & 14.1 \\
\hline Crustaceans (unid.) & - & - & 3.9 & 17.4 \\
\hline Cephalopods & - & - & 14.3 & 4.7 \\
\hline Cololabis saira & - & - & 8.1 & 0.7 \\
\hline Engraulis mordax & - & - & 67.8 & 29.8 \\
\hline Sardinops sagax & - & - & 0.0 & 4.3 \\
\hline Sebastes spp. & - & - & 0.1 & 4.3 \\
\hline Merluccius productus & - & - & 0.0 & 20.9 \\
\hline Trachurus symmetricus & - & - & 0.0 & 0.0 \\
\hline Myctophidae & - & - & 5.4 & 0.5 \\
\hline Paralepididae & - & - & 0.1 & 0.0 \\
\hline Vinciguerria lucetia & - & - & 0.0 & 0.0 \\
\hline Fishes (other) & - & - & 0.3 & 2.5 \\
\hline \multicolumn{5}{|l|}{ Central } \\
\hline Amphipods & 0.9 & 0.1 & 0.3 & 1.2 \\
\hline Pleuroncodes planipes & 0.0 & 0.0 & 0.0 & 0.0 \\
\hline Euphausiids & 6.5 & 0.4 & 2.6 & 0.4 \\
\hline Crustaceans (unid.) & 3.4 & 0.0 & 0.1 & 0.3 \\
\hline Cephalopods & 11.6 & 10.3 & 63.3 & 18.9 \\
\hline Cololabis saira & 22.3 & 85.1 & 17.2 & 30.5 \\
\hline Engraulis mordax & 37.6 & 0.0 & 2.1 & 1.5 \\
\hline Sardinops sagax & 0.0 & 0.0 & 0.0 & 0.5 \\
\hline Sebastes spp. & 1.5 & 0.0 & 1.1 & 2.8 \\
\hline Merluccius productus & 0.0 & 0.0 & 0.0 & 37.6 \\
\hline Trachurus symmetricus & 0.0 & 0.0 & 0.0 & 0.0 \\
\hline Myctophidae & 1.2 & 1.1 & 8.6 & 0.6 \\
\hline Paralepididae & 0.0 & 0.0 & 0.4 & 0.0 \\
\hline Vinciguerria lucetia & 0.0 & 0.0 & 0.0 & 0.0 \\
\hline Fishes (other) & 15.0 & 3.0 & 4.3 & 5.7 \\
\hline \multicolumn{5}{|l|}{ Southern } \\
\hline Amphipods & 1.4 & - & 0.0 & 0.5 \\
\hline Pleuroncodes planipes & 5.8 & - & 0.3 & 0.0 \\
\hline Euphausiids & 3.5 & - & 0.1 & 0.1 \\
\hline Crustaceans (unid.) & 0.4 & - & 0.0 & 3.5 \\
\hline Cephalopods & 9.0 & - & 18.5 & 11.4 \\
\hline Cololabis saira & 61.4 & - & 59.1 & 0.4 \\
\hline Engraulis mordax & 2.8 & - & 17.1 & 67.4 \\
\hline Sardinops sagax & 0.0 & - & 0.0 & 15.3 \\
\hline Sebastes spp. & 0.9 & - & 0.4 & 0.0 \\
\hline Merluccius productus & 1.8 & - & 0.0 & 0.0 \\
\hline Trachurus symmetricus & 0.0 & - & 0.1 & 0.0 \\
\hline Myctophidae & 0.7 & - & 0.6 & 0.0 \\
\hline Paralepididae & 0.0 & - & 0.1 & 0.0 \\
\hline Vinciguerria lucetia & 3.3 & - & 0.0 & 0.0 \\
\hline Fishes (other) & 8.9 & - & 3.8 & 1.5 \\
\hline
\end{tabular}

1948), saury were the dominant prey off Oregon during 1970 (Pearcy 1973), and juvenile anchovy were the dominant prey off Southern California during 1983 (Bernard et al. 1985). Finally, cephalopods were an 
Table 5. Thunnus alalunga. Estimates of diet-derived bioenergetic parameters (mean $\pm \mathrm{SD}$ ) for juvenile albacore from 4 diet studies. Values were calculated from aggregated study data (not separated into regions). The ensembleED is the weighted mean energy density value. Consumption rate and daily demand (prey biomass consumed at steady-state) were calculated using a bioenergetics model (Essington 2003) for an age-3 albacore of mean weight (5.9 kg)

\begin{tabular}{|c|c|c|c|c|}
\hline $\begin{array}{l}\text { Data } \\
\text { collection }\end{array}$ & $\begin{array}{l}\text { Ensemble } \\
E D\left(\mathrm{~kJ} \mathrm{~g}^{-1}\right)\end{array}$ & $\begin{array}{c}\text { Consumption } \\
\left(\mathrm{g} \mathrm{g}^{-1} \mathrm{~d}^{-1}\right)\end{array}$ & $\begin{array}{c}\text { Demand } \\
\left(\mathrm{g} \text { albacore } \mathrm{e}^{-1} \mathrm{~d}^{-1}\right)\end{array}$ & Source \\
\hline 1949-1950 & $6.0 \pm 0.9$ & $0.021 \pm 0.005$ & $124.5 \pm 28.8$ & McHugh (1952) \\
\hline 1954-1957 & $7.0 \pm 0.9$ & $0.018 \pm 0.004$ & $105.7 \pm 20.9$ & Iversen (1962) \\
\hline 1968-1969 & $6.2 \pm 0.7$ & $0.020 \pm 0.004$ & $120.4 \pm 26.0$ & Pinkas et al. (1971) \\
\hline 2005-2006 & $6.2 \pm 0.9$ & $0.020 \pm 0.004$ & $119.6 \pm 24.7$ & This study \\
\hline
\end{tabular}
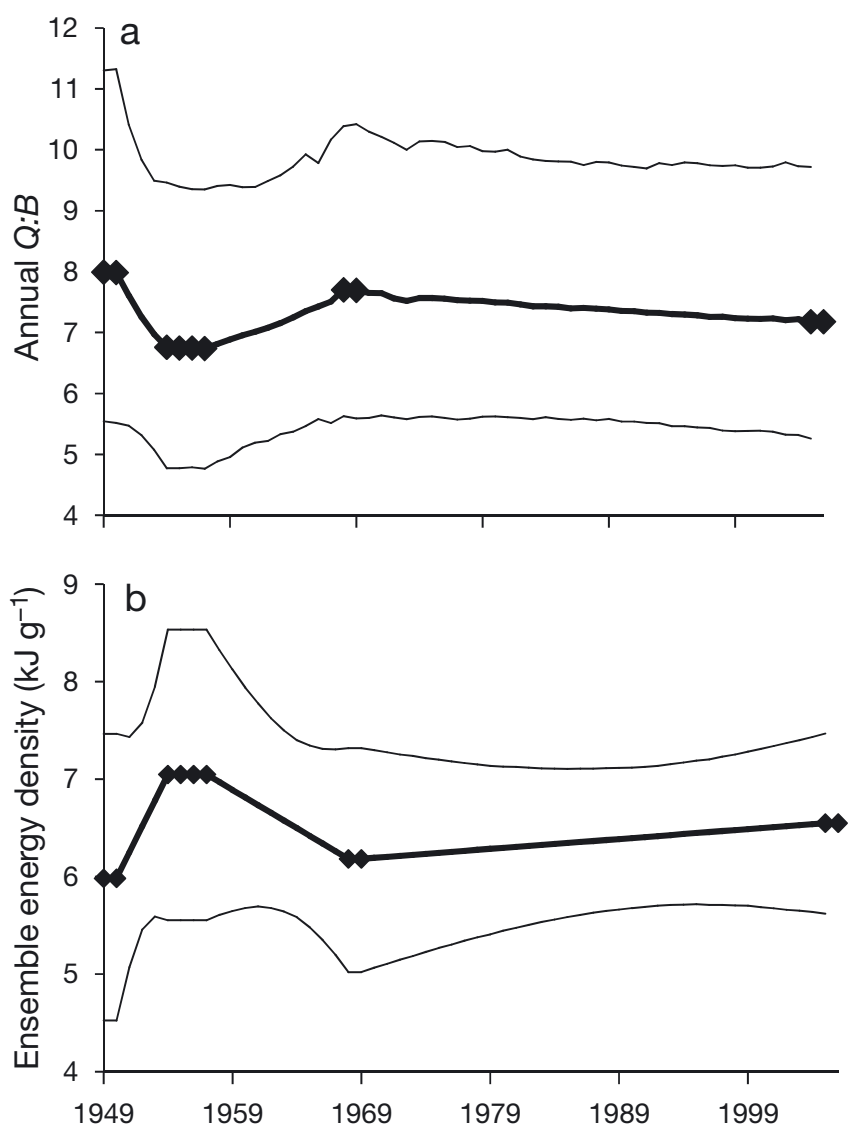

Fig. 3. Thunnus alalunga. Consumption metrics for juvenile albacore in the California Current System calculated from a bioenergetics model (Essington 2003). ( $\bullet$ years when data from a diet study parameterized the model; years between studies were extrapolated. The $90 \%$ confidence intervals (thin line) were obtained from a Monte Carlo simulation. (a) Annual consumption to biomass ratio $(Q: B)$. (b) Ensemble energy density $\left(E D_{n}\right)$ of prey suite

important component of albacore diet in all 3 regions investigated.

There have been important spatial and temporal exceptions to these general patterns. Saury occurred in much lower proportions in juvenile albacore diet in the northern region (note that Pearcy 1973 found significant amounts of saury in diet in this region, but data were collected over only $6 \mathrm{~d}$ and from a limited spatial area). Crustaceans were significant only in the northern region in one study (2005-2006). Anchovy were always important in the northern region, but were only found in large quantities in the central region during 1954-1957 when they were not found in the southern region. For all other studies, including one sampling trip in 1983 (Bernard et al. 1985), anchovy were important in the southern region. Hake were an important component in the northern and central regions during 2005-2006, but were not documented in notable quantities in other studies. Finally, sardine were important in the southern region (and occurred in the northern region) during 2005-2006, but not elsewhere.

It has long been hypothesized (Laurs \& Lynn 1991), and more recently demonstrated (Barr 2009), that the juvenile albacore population in the CCS is made up of northern and southern subpopulations, split around $40^{\circ} \mathrm{N}$, with differing migration routes and possibly growth rates. In diet, saury were less abundant north of $44^{\circ} \mathrm{N}$, and hake were absent south of $33^{\circ} \mathrm{N}$. Otherwise, there are no strong regional patterns to diet that could differentially affect these subpopulations.

Juvenile albacore prey almost exclusively on YOY fishes, with the exception of predation on adult saury. Data collected in 2005-2006 quantify these results, while the discussions of prey sizes in historical studies corroborate them. Comments by Hart et al. (1948), Iversen (1962), and Pinkas et al. (1971) suggested fish prey were of juvenile sizes. Measurements of individual volume (McHugh 1952) and length (Bernard et al. 1985) demonstrated that fact. Finally, albacore also consumed juvenile (but not adult) Japanese anchovy Engraulis japonicus in the Western Pacific Ocean (Watanabe et al. 2004).

\section{Prey preferences: anchovy over sardine}

The CCS contains many species of forage fish: anchovy, saury, hake, sardine, jack mackerel Trachurus symmetricus, and Pacific mackerel Scomber japonicus. Jack mackerel and Pacific mackerel have never been found in significant quantities as prey of albacore, and sardine were only important in the southern region during 2005-2006. These results belie the conventional wisdom that albacore are true generalists (Pinkas et al. 1971, Watanabe et al. 2004, Consoli et al. 
2008) and suggest that albacore have diet preferences. Without concurrently quantifying relative abundance of prey, in particular of YOY fishes, I cannot demonstrate that juvenile albacore are selectively consuming anchovy, saury, and sometimes hake over sardine and mackerel. Nevertheless, observational evidence suggests that juvenile albacore are not consuming prey in proportion to their relative abundance at the scale of the California Current ecosystem.

Continuous long-term biomass time series for YOY fishes are available for hake and Pacific mackerel (1966 to present and 1929 to present, respectively). Sardine time series contain a gap from 1964 to 1981, anchovy data span 1963 to 1994 and are limited to the southern subpopulation, and jack mackerel and saury are not assessed (Fig. 4). Consequently, the 2 primary prey species are too data-poor to make conclusive statements about preference or selectivity. However, Fig. 4 does support some conjecture. When time series coincide, YOY Pacific mackerel were considerably less abundant than sardine, anchovy, or hake, and they did not appear in albacore diet. During 1968-1969 (Pinkas et al. 1971), abundance of YOY anchovy and hake were comparable; sardine were not assessed but were assumed to have been far less abundant (Jacobson \& MacCall 1995). By the 2005-2006 study, anchovy assessments were no longer carried out. Sardine recruitment has been high over the past 2 decades, and YOY sardine were more abundant than YOY hake and likely were more abundant than anchovy during 2005 and 2006 (Hill et al. 2007). Thus, one might expect sardine to be more common in diet recently if relative abundance in the CCS were the dominant predictor of diet habits.

These 4 diet studies failed to find sardine in significant quantities, with the important exception of the southern region during 2005-2006. Thus, while it is assumed that sardine were higher in abundance than anchovy in the CCS during this period (Hill et al. 2007), the diet of albacore did not reflect a major shift in prey species from anchovy to sardine. However, the finding of significant predation on sardine in the southern CCS indicates that, during periods of higher sardine abundance, albacore can and do consume them. Sardine recruitment during 2005 and 2006 was higher than during the 1950s and 1960s (when past diet studies were conducted), but recruitment was lower on average than over the past decade (Hill et al. 2007, Fig. 4). Had diet data been col-
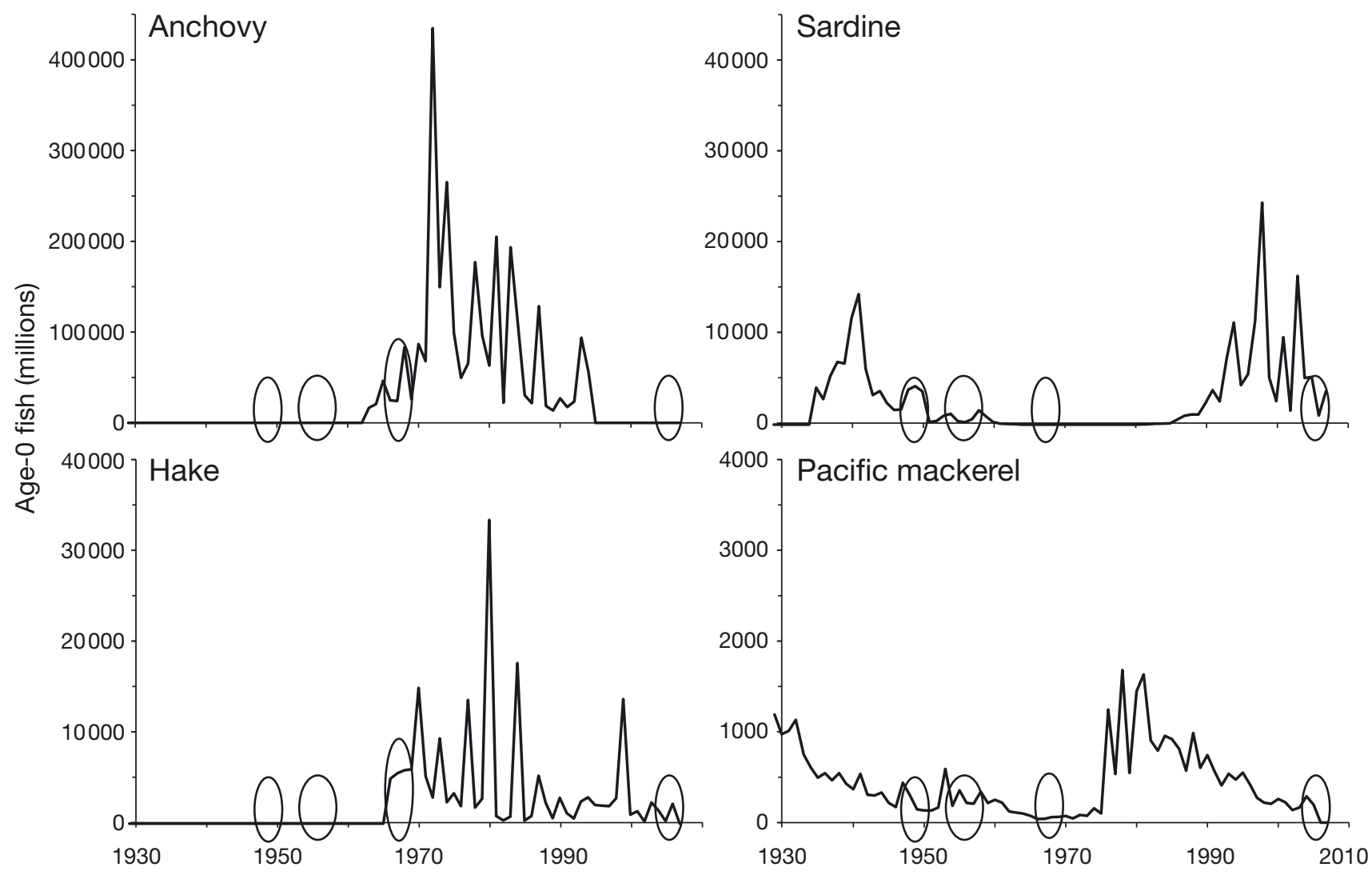

Fig. 4. Time series of abundance for age-0 (recruitment) anchovy (Jacobson et al. 1995), sardine (Jacobson \& MacCall 1995, Hill et al. 2007), hake (Helser et al. 2006), and Pacific mackerel (Hill \& Crone 2005). Diet study years are circled. Note the different $y$-axes. For anchovy, biomass was converted to numbers based on a mean weight of age-0 anchovy of $10 \mathrm{~g}$ (Methot 1989) 
lected during years of high sardine recruitment (e.g. 1998 or 2003), predation on juvenile sardine may have rivaled or exceeded predation on anchovy.

Several important caveats to these conjectures must be made. First, the population estimates from which Fig. 4 was constructed are age-based stock assessments associated with high uncertainty in mortality rates and thus in recruitment biomass (see assessment reports cited). Second, the time series describe populations or subpopulations that do not fully overlap each other or span the CCS. Anchovy data are for the central substock residing south of $35^{\circ} \mathrm{N}$ (Jacobson et al. 1995a), and anchovy biomass estimates for the northern substock do not exist. Furthermore, with a possible northward shift in hake spawning grounds (Phillips et al. 2007), the hake population is unlikely to overlap the southern anchovy population. Finally, adult sardine and mackerel tend to occupy waters further offshore than hake or anchovy (Agostini et al. 2006, Checkley et al. 2000). Consequently, inferences must be made carefully; data simply are not available to conclude whether active preferences in albacore diet exist.

\section{Thermal preferences drive predation}

Optimal foraging theory provides several hypotheses for why albacore may consume anchovy, saury, and (recently) hake instead of sardine (MacArthur \& Pianka 1966, Kirby et al. 2000). First, sardine could be faster swimmers than other species and therefore more costly to chase. However, at the size consumed by albacore during summer and fall months, there is little difference in swimming speed of sardine and anchovy (van der Lingen 1995). Second, sardine could be of inferior energetic quality (Emlen 1966); however, sardine is considerably higher in ED than hake, slightly higher than anchovy, and only slightly lower than saury (Table 3). Third, albacore may not co-exist with sardine at mesoscales or during feeding events.

Adult sardine live further offshore than anchovy, saury, or juvenile hake, and the species have distinct spawning regions (Checkley et al. 2000). Sardine spawn in warmer $\left(13^{\circ}\right.$ to $\left.25^{\circ} \mathrm{C}\right)$ offshore waters (LluchBelda et al. 1991) subject to weaker, slower rates of curl-driven upwelling (Rykaczewski \& Checkley 2008), whereas anchovy and saury spawn in colder nearshore waters with stronger coastal upwelling [respectively, 11.5 to $16.5^{\circ} \mathrm{C}$ (Lluch-Belda et al. 1991) and 13 to $18^{\circ} \mathrm{C}$ (Kurita 2006)]. Newly spawned hake are found in nearshore waters during spring and summer (Saunders \& McFarlane 1997). The optimal thermal range for albacore is 16 to $19^{\circ} \mathrm{C}$, and optimal foraging models predict albacore will hunt in waters just above the threshold at which thermal stress accu- mulates (Kirby et al. 2000). Under conditions of uniform prey, albacore hunt in cold, nearshore waters to the exclusion of warmer, offshore waters (Kirby et al. 2000). Under conditions of variable prey abundance and energy densities, albacore are predicted to occupy warmer offshore waters when satiated, but the majority of daylight hours would be spent foraging in colder nearshore waters. This study empirically supports the model predictions of Kirby et al. (2000): juvenile albacore prefer hunting in the habitat of YOY anchovy, saury, and hake to that of sardine, even during periods of high sardine abundance.

It is possible that data collection did not adequately sample sardine habitat, especially given that sardine live further offshore than anchovy, and fishing vessels have economic incentives to stay as close to shore as possible. However, sampling locations did occur within the spatial extent of sardine spawning habitat described by egg distributions (Checkley et al. 2000) in the southern CCS, and egg, larval, and adult distributions in the northern CCS (Emmett et al. 2005).

These results raise an interesting question regarding sardine and anchovy population dynamics. Over the past century, the populations of these 2 coastal pelagic species have fluctuated asynchronously (Soutar \& Isaacs 1974, Schwartzlose et al. 1999). While many explanations have been advanced, environmental factors may be the root cause (Chavez et al. 2003, Rykaczewski \& Checkley 2008). If sardine and anchovy do not occupy the same water masses (Checkley et al. 2000), do not eat the same prey (van der Lingen 1995), and do not have the same predators, can the 2 species be considered competitors?

The absence of hake from all but one diet study can be explained by the episodic nature of hake spawning and recruitment (Horne \& Smith 1997, Lo et al. 1997, Agostini et al. 2006, Phillips et al. 2007). Hake have the highest degree of spatial patchiness in egg and larval distribution of any fish in the CCS (Lo et al. 1997) and the geographic center of hake spawning can move annually (Horne \& Smith 1997, Phillips et al. 2007). Abundance is also highly patchy in time, being 3 to 10 times greater in outstanding years of recruitment than in an average year (Horne \& Smith 1997). None of the major spikes in hake recruitment co-occurred with the 3 historical diet studies. The absence of hake prey in those studies could be due to a temporal mis-match in hake spawning and albacore predation, or a temporal or spatial mis-match in hake presence and stomach sampling. Furthermore, the finding of hake in diet in the central and northern regions during 2005-2006 is corroborated by high relative values of hake catch per unit effort (CPUE) during 2003 to 2006 compared to the previous 4 decades (although, strikingly, CPUE was lowest during 2005-2006) (Phillips et al. 2007). 


\section{Reconceptualizing albacore foraging}

This study reconceptualizes historical diet studies by translating numeric gut content data into the currency of energetics. Energetic values are the most accurate way to quantify the importance of a prey item to the growth of the predator (Wallace 1981, Probst et al. 1984, Pope et al. 2001). Numerous indices can be used to quantify diet habits, such as the Index of Relative Importance (Pinkas et al. 1971), the Geometric Importance Index (Assis 1996), mean stomach fullness (Pope et al. 2001), and simple metrics of number, volume, or frequency of occurrence of prey. Energetic contribution avoids over-emphasizing small but numerous prey (e.g. euphausiids) or prey that occur regularly but in small numbers, and is a biologically meaningful quantity. In this light, the diet habits of albacore appear less diverse than presumed in the past. For example, Pinkas et al. (1971) emphasize the importance of crustaceans, in particular euphausiids, to albacore diet. However, when ED is taken into account, crustaceans are insignificant: only 1 of 4 studies found $E$ greater than $3 \%$. Likewise, cephalopods were $30 \%$ of energetic intake during the 1968-1969 study, but elsewhere they contributed less than $12 \%$. If only species richness of diet is considered, the 10 species of cephalopods consumed make diet appear more diverse. While the importance of weak predator-prey interactions should not be ignored (McCann et al. 1998), research efforts could focus on a more narrow range of prey.

This refined view of juvenile albacore diet habits suggests that their classification as generalist predators should be qualified. Undoubtedly juvenile albacore 'eat what they see', a characteristic of opportunists. However, what they see may be confined to a particular environment - in this case, to that favoring juvenile anchovy, saury, and hake. Therefore, the scale at which predation is viewed becomes critical. If one conceptualizes the entire CCS as an aggregated food web, as many ecosystem models do (e.g. Field et al. 2006), albacore do not consume some species (namely, sardine) in proportion to abundance in the environment. However, when smaller spatial scales are considered, albacore consume prey they encounter, possibly in proportion to the rate of encounter.

\section{Importance of energy density and diet stability}

Accounting for variability in prey $E D$ is important for accurate modeling of predator consumption rates (Stewart \& Binkowski 1986). ED values can differ significantly within a species, depending primarily on reproductive status (Kitts 2004) and size (Ciannelli et al. 2002). However, other studies have shown weak or no relationships between size and ED (Payne et al. 1999, Eder \& Lewis 2005). In the case of North Pacific albacore, prey spawning status is uniform (reproductively immature) and the size distribution of prey is narrowly confined to YOY sizes. Thus, the most relevant evidence for interpreting variability in $E D$ comes from studies that focus on juvenile fishes (Arrhenius \& Hansson 1996, Ciannelli et al. 2002, Tirelli et al. 2006). Among juvenile fishes, ED increases linearly with growth, but the intraspecies variability at any given time is low. Thus, when focusing on a subpopulation of predators in a given region and season, interspecies variability in prey $E D$ is more important than intraspecies variability due to size or spawning status.

The choice of $E D_{n}$ used in a bioenergetics model can have a significant impact on calculated consumption rates for certain types of predators (Fig. 2). There is a geometrically decreasing relationship between the biomass a predator must consume to maintain stable energetic intake and the $E D_{n}$ of prey. The steepest portion of the curve in Fig. 2 demonstrates the importance of calculating $E D_{n}$ using weighted means. For example, if albacore diet were $75 \%$ Pleuroncodes planipes (a pelagic decapod) and $25 \%$ Engraulis mordax, $E D_{n}$ would be $3.9 \mathrm{~kJ} \mathrm{~g}^{-1}$ and an age-3 albacore would need to consume $190.5 \mathrm{~g} \mathrm{~d}^{-1}$, or $3.2 \%$ of its body weight, to maintain stable energetic intake or growth. However, if diet were $25 \%$ P. planipes and $75 \%$ E. mordax, $E D_{n}$ would be $5.8 \mathrm{~kJ} \mathrm{~g}^{-1}$ and that same albacore would need to consume only $128.8 \mathrm{~g} \mathrm{~d}^{-1}$, or $2.2 \%$ of body weight. Furthermore, the arithmetic (non-weighted) mean of the individual $E D$ values is $4.8 \mathrm{~kJ} \mathrm{~g}^{-1}$, inaccurately quantifying consumption of $154.8 \mathrm{~g} \mathrm{~d}^{-1}$. When scaled to the population level, as in ecosystem models, these inaccuracies become significant. Thus, unless prey are consumed in uniform proportions, an ensemble ED must be calculated as a weighted mean.

Although the 3 main prey items of albacore vary in $E D$, the range of values lies on the asymptotic portion of the curve in Fig. 2 and energetic tradeoffs between prey items may be of small consequence to daily biomass consumption. Hypothetically, a $25 \%$ difference in daily demand could impact growth rates. However, given the proportional composition of species in albacore diet, the $E D_{n}$ values are strikingly similar. This suggests that albacore maintain a stable base of prey — from an energetics standpoint. Finally, it should be noted that fish are unlikely to adjust biomass consumption while holding growth constant, or to change growth rate while holding consumption rates constant. More likely, there is plasticity in both rates and the overall impact would be a less pronounced adjustment to both. 
This is not to neglect the possibility of detrimental shifts in prey quality in the future, nor to discount the importance of variable $E D_{n}$ in other types of predators. Changes in relative $E D$ can explain predator preferences in prey (Mohn \& Bowen 1996, Stenson et al. 1997), and declines in $E D_{n}$ have been linked to declining predator populations (Lawson et al. 1998, Kitts 2004). If the suite of prey available to juvenile albacore in the CCS were to change significantly, particularly if anchovy or saury were replaced by lower energy prey, juvenile albacore would either switch prey, increase rates of biomass consumption, or face declining growth rates. In general, the type of predator is a critical consideration when assessing variable prey ED. For predators that consume primarily crustaceans or other lowED prey (the steep portion of the curve in Fig. 2), interspecies variability can lead to dramatic differences in daily rates. However, for piscivores or predators that consume high ED prey (the flat portion of the curve in Fig. 2), the interspecies differences may contribute much less to overall variability in growth rates or population dynamics.

The low variability in $E D_{n}$ translates into equally stable $Q: B$. The value for $Q: B$ calculated here (mean 7.3) is lower than the 13.4 calculated by Essington (2003), but his model used a mean ED value of 5.0 and applied to the full North Pacific population of albacore (adults significantly increase the ratio). While these $Q: B$ ratios are specific to juvenile North Pacific albacore in the CCS, the estimates of uncertainty can be used to guide input to models of other species and systems. As ecosystem models begin to incorporate measurements of uncertainty, field-verified data such as these are increasingly needed (Christensen \& Walters 2004).

Results from the past $50 \mathrm{yr}$ should offer some reassurance that diet, biomass consumption and $E D_{n}$ values for juvenile albacore are stable, even during periods of widespread change in the CCS (e.g. Hare \& Mantua 2000, McGowan et al. 2003). Lavaniegos \& Ohman (2007) showed that carbon biomass of zooplankton in the CCS has remained stable throughout the oceanic changes evident during 1976 to 1977. Despite changes in species composition of zooplankton since the mid-1950s (Ohman \& Venrick 2003), the total biomass of zooplankton has remained stable. Although zooplankton are not a major source of energy to albacore, stable carbon biomass estimates at these lower trophic levels suggest that the overall food web has redundancies.

This study supports recent calls (Link 2007) to expand data collection for species that are not currently assessed. Heavy fishing pressure has been linked to serial depletion of top predators: when one commercial species is fished to low abundances, fisheries have economic incentives to switch target species and changes to the food web result (Pauly et al. 2002, Link 2007). Newly fished species are rarely as well studied as historically profitable fisheries, an alarming aspect of serial depletion (Pauly et al. 2002). This scenario has a likelihood of being repeated in the CCS. The dearth of data describing saury in the CCS, and the short time series of anchovy biomass, make it impossible to know whether the recent increase in hake in albacore diet is a result of fewer anchovy or saury in the environment. In the CCS, human catches of anchovy and saury are low and zero, respectively, suggesting juvenile albacore are not directly competing with humans for their most important prey items. However, humans already have expanded fisheries into previously unharvested species, and the trend will continue in order to sustain world protein demand (Pauly et al. 2002). Collection of more thorough data on saury and resumption of stock assessments of anchovy may be prudent undertakings now, before these stocks face new fishing pressure. Failure to understand and document long-term changes in these critical prey species may one day inhibit our study of the population dynamics of a commercially important marine predator.

Acknowledgements. I am grateful to the students, researchers, and fishing vessels who contributed to this study: J. Lagrange, T. Mattusch, K. \& K. Vanderpool, P. Svornich, M. Medak, K. Honkola, M. Stowe, B. Monroe, H. Dewar, R. Rykaczewski, N. Mehaffie, R. Combs, A. McBeth, R. Waddell, J. Weddell, A. Preti, F. G. E. Hochberg, A. Townsend, M. Lowry, J. Hyde, and R. Vetter. I thank D. Checkley, G. Watters, M. Ohman, B. Werner, T. Essington, G. Sugihara, and J. Kohn for providing valuable reviews on drafts of this manuscript. This research was funded by National Sea Grant, California Sea Grant, and a research grant from the American Fisherman's Research Foundation.

\section{LITERATURE CITED}

Agostini VN, Francis RC, Hollowed AB, Pierce SD, Wilson C, Hendrix AN (2006) The relationship between Pacific hake (Merluccius productus) distribution and poleward subsurface flow in the California Current System. Can J Fish Aquat Sci 63:2648-2659

Arrhenius F, Hansson S (1996) Growth and seasonal changes in energy content of young Baltic Sea herring (Clupea harengus L). ICES J Mar Sci 53:792-801

Assis CA (1996) A generalised index for stomach contents analysis in fish. Sci Mar 60:385-389

Barr CM (2009) Are there two subgroups of albacore, Thunnus alalunga, in the North Pacific? Evidence from variability in catch, seasonal migrations, and length composition for two subgroups in the coastal fishery of North America. Masters thesis, Oregon State University, Corvallis, OR

Baumgartner TR, Soutar A, Ferreirabartrina V (1992) Reconstruction of the history of Pacific sardine and Northern anchovy populations over the past 2 millennia from sediments of the Santa Barbara Basin, California. Calif Coop Ocean Fish Invest Rep 33:24-40

Bernard HJ, Hedgepeth JB, Reilly SB (1985) Stomach con- 
tents of albacore, skipjack, and bonito caught off Southern California during summer 1983. Calif Coop Ocean Fish Invest Rep 26:175-182

Brodeur RD, Fisher JP, Emmett RL, Morgan CA, Casillas E (2005) Species composition and community structure of pelagic nekton off Oregon and Washington under variable oceanographic conditions. Mar Ecol Prog Ser 298:41-57

Chavez FP, Ryan J, Lluch-Cota SE, Niquen M (2003) From anchovies to sardines and back: multidecadal change in the Pacific Ocean. Science 299:217-221

Checkley DM Jr., Dotson RC, Griffith DA (2000) Continuous, underway sampling of eggs of Pacific sardine (Sardinops sagax) and northern anchovy (Engraulis mordax) in spring 1996 and 1997 off southern and central California. DeepSea Res II 47:1139-1155

> Christensen V, Walters CJ (2004) Ecopath with Ecosim: methods, capabilities and limitations. Ecol Modell 172:109-139

> Ciannelli L, Paul AJ, Brodeur RD (2002) Regional, interannual and size-related variation of age 0 year walleye pollock whole body energy content around the Pribilof Islands, Bering Sea. J Fish Biol 60:1267-1279

Clarke MR (1986) A handbook for the identification of cephalopod beaks. Oxford University Press, New York

Clothier CR (1952) A key to some Southern California fishes based on vertebral characteristics. Fish Bull 79:1-87

Consoli P, Romeo T, Battaglia P, Castriota L, Esposito V, Andaloro F (2008) Feeding habits of the albacore tuna Thunnus alalunga (Perciformes, Scombridae) from central Mediterranean Sea. Mar Biol 155:113-120

Cox SP, Essington TE, Kitchell JF, Martell SJD, Walters CJ, Boggs C, Kaplan I (2002) Reconstructing ecosystem dynamics in the central Pacific Ocean, 1952-1998. II. A preliminary assessment of the trophic impacts of fishing and effects on tuna dynamics. Can J Fish Aquat Sci 59: 1736-1747

de Zarate VO, Restrepo V (2001) Analysis of tagging data from North albacore: von Bertalanffy growth estimates and catch-at-age. Collect Vol Sci Pap ICCAT 52:14351446

Eder EB, Lewis MN (2005) Proximate composition and energetic value of demersal and pelagic prey species from the SW Atlantic Ocean. Mar Ecol Prog Ser 291:43-52

Emlen JM (1966) The role of time and energy in food preference. Am Nat 100:611-618

Emmett RL, Brodeur RD, Miller TW, Pool SS, Krutzikowsky GK, Bentley PJ, McCrae J (2005) Pacific sardine (Sardinops sagax) abundance, distribution, and ecological relationships in the Pacific Northwest. Calif Coop Ocean Fish Invest Rep 46:122-143

Essington TE (2003) Development and sensitivity analysis of bioenergetics models for skipjack tuna and albacore: A comparison of alternative life histories. Trans Am Fish Soc 132:759-770

Field JC, Francis RC, Aydin K (2006) Top-down modeling and bottom-up dynamics: Linking a fisheries-based ecosystem model with climate. Prog Oceanogr 68:238-270

Froese F, Pauly D (2008) FishBase. Accessed Feb 2008. www.fishbase.org

Graham JJ (1959) Northeastern Pacific albacore survey. Part 1. Biological observations. Fisheries Report no. 310

Hare SR, Mantua NJ (2000) Empirical evidence for North Pacific regime shifts in 1977 and 1989. Prog Oceanogr 47: 103-145

Hart JL, Barraclough WE, Pike GC, Bethune W (1948) Accumulated data on albacore (Thunnus alalunga). Pacific Biological Station, Fisheries Research Board of Canada. No. 12
Harvey JT, Loughlin TR, Perez MA, Oxman DS (2000) Relationship between fish size and otolith length for 63 species of fishes from the eastern North Pacific Ocean. NOAA Tech Rep 150:1-36

Helser TE, Stewart IJ, Fleischer GW, Martell S (2006) Stock assessment of Pacific hake (whiting) in U.S. and Canadian Waters in 2006. Northwest Fisheries Science Center, Seattle, WA

Hill KT, Crone PR (2005) Assessment of the Pacific mackerel (Scomber japonicus) stock for U.S. management in the 2005-2006 season. Pacific Fisheries Management Council, Portland, OR

Hill KT, Dorval E, Lo NCH, Macewicz BJ, Show C, FelixUraga R (2007) Assessment of the Pacific sardine resource in 2007 for US management in 2008. NOAA Tech Memo NOAA-TM-NMFS-SWFSC-413, US Dept Commerce

Hollowed AB, Bax N, Beamish R, Collie J and others (2000) Are multispecies models an improvement on single-species models for measuring fishing impacts on marine ecosystems? ICES J Mar Sci 57:707-719

Horne JK, Smith PE (1997) Space and time scales in Pacific hake recruitment processes: latitudinal variation over annual cycles. Calif Coop Ocean Fish Invest Rep 38: 90-102

> Hsieh CH, Glaser SM, Lucas AJ, Sugihara G (2005) Distinguishing random environmental fluctuations from ecological catastrophes for the North Pacific Ocean. Nature 435: $336-340$

Isaacs JD, Fleminger A, Miller JK (1969) Distributional atlas of zooplankton biomass in the California Current region: spring and fall 1955-1959. Calif Coop Fish Invest Atlas, 10

ISC (2006) Report of the ISC-Albacore Working Group Stock Assessment Workshop, National Research Institute of Far Seas Fisheries, Shimizu

Iversen RTB (1962) Food of albacore tuna, Thunnus germo (Lacepede), in the central and northeastern Pacific. Fish Bull 62:459-481

Jacobson LD, MacCall AD (1995) Stock-recruitment models for Pacific sardine (Sardinops sagax). Can J Fish Aquat Sci 52:566-577

Jacobson LD, Lo NCH, Herrick SF, Bishop T (1995) Spawning biomass of the Northern anchovy in 1995 and status of the coastal pelagic fishery during 1994. Administrative Report LJ-95-11. National Marine Fisheries Service, La Jolla, CA

$>$ Kimura S, Munenori N, Sugimoto T (1997) Migrations of albacore, Thunnus alalunga, in the North Pacific Ocean in relation to large oceanic phenomena. Fish Oceanogr 6:51-57

> Kirby DS, Fiksen O, Hart PJB (2000) A dynamic optimisation model for the behaviour of tunas at ocean fronts. Fish Oceanogr 9:328-342

Kitchell JF, Boggs CH, He X, Walters CJ (1999) Keystone predators in the central Pacific. In: Ecosystem approaches for fisheries management. University of Alaska Sea Grant AK-SG-99-01, Fairbanks, AK, p 665-683

Kitts DD, Huynh MD, Hu C, Trites AW (2004) Season variation in nutrient composition of Alaskan walleye pollock. Can J Zool 82:1408-1415

Kurita Y (2006) Regional and interannual variations in spawning activity of Pacific saury, Cololabis saira, during northward migration in spring in the north-western Pacific. J Fish Biol 69:846-859

Laurs RM, Lynn RJ (1977) Seasonal migration of North Pacific albacore, Thunnus alalunga, into North American coastal waters - distribution, relative abundance, and association with transition zone waters. Fish Bull 75:795-822

Laurs RM, Lynn RJ (1991) North Pacific albacore ecology and oceanography. NOAA Tech Rep 105:69-87 
Lavaniegos BE, Ohman MD (2007) Coherence of long-term variations of zooplankton in two sectors of the California Current System. Prog Oceanogr 75:42-69

Lawson JW, Anderson JT, Dalley EL, Stenson GB (1998) Selective foraging by harp seals Phoca groenlandica in nearshore and offshore waters of Newfoundland, 1993 and 1994. Mar Ecol Prog Ser 163:1-10

Link JS (2007) Underappreciated species in ecology: 'ugly fish' in the northwest Atlantic Ocean. Ecol Appl 17:2037-2060

Lluch-Belda D, Lluch-Cota DB, Hernandez-Vazquez S, Salinas-Zavala CA (1991) Sardine and anchovy spawning as related to temperature and upwelling in the California Current System. Calif Coop Ocean Fish Invest Rep 32: 105-111

Lo NCH, Griffith D, Butler JR (1997) Using a restricted adaptive cluster sampling to estimate Pacific hake larval abundance. Calif Coop Ocean Fish Invest Rep 38:103-113

MacArthur R, Pianka E (1966) On optimal use of a patchy environment. Am Nat 100:603-609

McCann K, Hastings A, Huxel GR (1998) Weak trophic interactions and the balance of nature. Nature 395:794-798

McGowan JA, Bograd SJ, Lynn RJ, Miller AJ (2003) The biological response to the 1977 regime shift in the California Current. Deep-Sea Res II 50:2567-2582

McHugh JL (1952) The food of albacore (Germo alalunga) off California and Baja California. Bull Scripps Inst Oceanogr 6:161-172

Methot RD (1989) Synthetic estimates of historical abundance and mortality for northern anchovy. Am Fish Soc Symp 6:66-82

Mohn R, Bowen WD (1996) Grey seal predation on the eastern Scotian Shelf: Modelling the impact on Atlantic cod. Can J Fish Aquat Sci 53:2722-2738

Ohman MD, Venrick EL (2003) CalCOFI in a changing ocean. Oceanography (Wash DC) 16:76-86

Olson RJ, Boggs CH (1986) Apex predation by yellowfin tuna (Thunnus albacares): independent estimates from gastric evacuation and stomach contents, bioenergetics, and cesium concentrations. Can J Fish Aquat Sci 43:1760-1775

Olson RJ, Watters GM (2003) A model of the pelagic ecosystem in the Eastern tropical Pacific ocean, Vol. 22 No. 3. Inter-American Tropical Tuna Commission, La Jolla, CA

Pauly D (1989) Food consumption by tropical and temperate fish populations: some generalizations. J Fish Biol 35A: 11-20

Pauly D, Christensen V, Guenette S, Pitcher TJ and others (2002) Towards sustainability in world fisheries. Nature 418:689-695

Payne SA, Johnson BA, Otto RS (1999) Proximate composition of some North-Eastern Pacific forage fish species. Fish Oceanogr 8:159-177

Pearcy W (1973) Albacore oceanography off Oregon - 1970. Fish Bull 71:489-504

Phillips AJ, Ralston S, Brodeur RD, Auth TD, Emmett RL, Johnson C, Wespestad VG (2007) Recent pre-recruit Pacific hake (Merluccius productus) occurrences in the Northern California Current suggest a northward expansion of their spawning area. CCOFI Rep 48:215-229

Pinkas L, Oliphant MS, Iverson ILK (1971) Food habits of

Editorial responsibility: John Piatt,

Anchorage, Alaska, USA albacore, bluefin tuna, and bonito in California waters. Fish Bull 152:2-83

Pope KL, Brown ML, Duffy WG, Michaletz PH (2001) A caloric-based evaluation of diet indices for largemouth bass. Environ Biol Fishes 61:329-339

Probst WE, Rabeni CF, Covington WG, Marteney RE (1984) Resource use by stream-dwelling rock bass and smallmouth bass. Trans Am Fish Soc 113:283-294

Roughgarden J (1974) Niche width: biogeographic patterns among Anolis lizard populations. Am Nat 108:429-442

> Rykaczewski RR, Checkley DMC (2008) Influence of ocean winds on the pelagic ecosystem in upwelling regions. Proc Natl Acad Sci USA 105:1965-1970

Saunders MW, McFarlane GA (1997) Observations on the spawning distribution and biology of offshore Pacific hake (Merluccius productus). Calif Coop Ocean Fish Invest Rep 38:147-157

Schwartzlose RA, Alheit J, Bakun A, Baumgartner TR and others (1999) Worldwide large-scale fluctuations of sardine and anchovy populations. S Afr J Mar Sci 21:289-347

Soutar A, Isaacs JD (1974) Abundance of pelagic fish during the 19th and 20th centuries as recorded in anaerobic sediment off the Californias. Fish Bull 72:257-273

Stenson GB, Hammill MO, Lawson JW (1997) Predations by harp seals in Atlantic Canada: preliminary consumption estimates for Arctic cod, capelin and Atlantic cod. J Northwest Atl Fish Sci 22:137-154

Stewart DJ, Binkowski FP (1986) Dynamics of consumption and food conversion by Lake Michigan alewives: an energetics-modeling synthesis. Trans Am Fish Soc 115: $643-661$

Suda A (1966) Catch variation in the north Pacific albacore VI. The speculations about the influences of fisheries on the catch and abundance of albacore in the north Pacific by use of some simplified mathematical models. Rep Nankai Reg Fish Res Lab 24:1-14

Tirelli V, Borme D, Tulli F, Cigar M, Umani SF, Brandt SB (2006) Energy density of anchovy Engraulis encrasicolus L. in the Adriatic Sea. J Fish Biol 68:982-989

van der Lingen CD (1995) Respiration rate of adult pilchard Sardinops sagax in relation to temperature, voluntary swimming speed and feeding behaviour. Mar Ecol Prog Ser 129:41-54

Wallace RK (1981) An assessment of diet-overlap indexes. Trans Am Fish Soc 110:72-76

Watanabe H, Kubodera T, Masuda S, Kawahara S (2004) Feeding habits of albacore Thunnus alalunga in the transition region of the central North Pacific. Fish Sci 70:573-579

Watters GM, Olson RJ, Francis RC, Fiedler PC and others (2003) Physical forcing and the dynamics of the pelagic ecosystem in the eastern tropical Pacific: simulations with ENSO-scale and global-warming climate drivers. Can J Fish Aquat Sci 60:1161-1175

Wolff GA (1984) Identification and estimation of size from the beaks of 18 species of cephalopods from the Pacific Ocean. NOAA Tech Rep, Vol 17, NMFS, Seattle, WA

> Wootton JT (1997) Estimates and tests of per capita interaction strength: diet, abundance, and impact of intertidally foraging birds. Ecol Monogr 67:45-64

Submitted: August 24, 2009; Accepted: July 5, 2010

Proofs received from author(s): August 24, 2010 